\title{
The Best Interest of the Child Principle in the Juvenile Justice System
}

\author{
Sasmita Adika Candra ${ }^{1}$; Rodliyah ${ }^{1}$; L.Parman ${ }^{2}$ \\ ${ }^{1}$ Student of Magister Law Study Program, Postgraduate Program, Mataram University, Indonesia \\ ${ }^{2}$ Lecture of Law Faculty Mataram University, Indonesia
}

http://dx.doi.org/10.18415/ijmmu.v6i4.1017

\begin{abstract}
Children are Nation Assets who have limitations in understanding and protecting themselves from the various influences of the existing system, therefore protection efforts are needed. Research Objectives analyze the concept of the best interests of children in the juvenile criminal justice system, the application of the principle of best interest for children in sexual abuse cases in the Central Lombok Police Station. Empirical legal research methods. Results of research Setting the principle of best interest for children in Law Number 11 of 2012 concerning the Child Judicial System in the provisions of Article 2 letter d. The application of the principle of best interest for children in the Central Lombok Resort Police, suspects are not treated the same as adults, given the opportunity to go to school, be examined in a special room that is a PPA unit room, a PPA special investigator and dressed non-official.
\end{abstract}

Keywords: Principles; Children and the Criminal Justice System for Children

\section{Introduction}

Children are the nation's assets that have limitations in understanding and protecting themselves from the various influences of the existing system, therefore it is necessary for the State's efforts to provide attention and protection so that in the future the child can make a major contribution to the progress of the State, besides that efforts This protection works so that children avoid mental, physical and social losses.

Protection of children can be seen from the provisions of the Convention on the Rights of the Child ratified by the Government of Indonesia through Presidential Decree Number 36 of 1990, which is then set forth in Law Number 4 of 1979 concerning Child Welfare and in the Law Law Number 23 Year 2002 concerning Child Protection and Law Number 11 Year 2012 concerning the Criminal Justice System for Children.

The overall rules state the general principles of child protection, namely regarding nondiscrimination, the best interests of children, survival and development and respect for children's participation. After knowing the description of children, the next definition will be discussed, namely the definition of children contained in the Convention on the Right of the Child (CRC) or KHK of the United 
Nations is every human being under the age of 18 years, except according to laws applies to children, maturity is achieved earlier.

An understanding of children can also be found in the provisions of Law No. 23 of 2002 concerning Child Protection which states that a child is not yet 18 (eighteen) years old, including children who are still in the womb. A child in undergoing his life process will definitely go through a phase or stages of life, while the phase that will be passed by the child is the adolescent phase, which is meant by the adolescent phase is a process of transition or periods of transfer from the phase of children to the adult phase, in this phase it is found that the child will exhibit anti-social behavior, then accompanied by a lot of heart and soul upheaval, this phase of the child can make the child lose control over his emotions, so to cope with this it requires coaching and supervision by all parties, especially the family, because if there is no coaching and supervision then being mistreated will lead to delinquency which can eventually lead to criminal acts.

The emergence of juvenile delinquency in the community not only arises due to lack of guidance and supervision, but delinquency can also arise due to the current of globalization followed by economic, scientific and technological developments that not only cause positive impacts but also cause negative impacts, such as increasingly the increasing crisis of moral values for children in society has the potential to cause many children to break the law.

Based on this description is a strong reason for writers to conduct research on the principle of the best interests of children in Law Number 11 of 2011 concerning the Juvenile Justice System because in Article 2 letter d of Law No.11 of 2012 concerning the Juvenile Justice System, it seems that the formulation of norms to Article 2 letter $d$ is still unclear and detailed. As a result of that, there is a blur in interpreting. The formulation of such norms is seen as important in protecting the rights of children as perpetrators of crime. That is why the authors are interested in conducting research with the title "The principle of the best interest for children in the Criminal Justice System for Children".

\section{Methods}

\section{Types of Research}

This research is an empirical study. Empirical legal research is a legal research method that seeks to see the law in a real sense or can be said to look at, examine how the law works in the community in this case related to the application of the best interest principle for children who commit crimes in the Central Lombok District Police Legal Area.

\section{Problem Approach}

The approach used in this study is as follows:

a. Statutory Approach (Statute Approach)

The Legislative Approach is an approach that is carried out by reviewing the laws and regulations relating to the problem under study.

b. Conceptual Approach

Besides that, a conceptual approach is also used, which is an approach that examines the views of experts and concepts of thought related to the best interest of the child principle in the juvenile justice system.

c. Sociological Approach

The sociological approach is an approach to see the law in reality in social life relating to cases that are the focus of research. 


\section{Result and Discussion}

\section{Arrangement of the Best Interest Principle for Children in Law Number 11 Year 2012 Regarding the Criminal Justice System for Children}

\subsection{Overview of Children}

\section{a. Definition of Children}

In general, what is meant by a child is a descendant or generation as a result of sexual relations or intercourse (sexual intercourse) between a man and a woman both in marriage and outside marriage. Then in customary law as stated by Soerojo Wignjodipoero quoted by Tholib Setiadi, it states that:

"Unless it is seen by their parents as the successor to the generation, the child is also seen as a container in which all the hopes of his parents will later be shed, also seen as a protector of his parents later if the parents are physically unable to make a living again."

\section{b. Legal Protection of Children}

Protection means as a way, process or act of protecting, while the law is a forceful regulation that determines human behavior in the community environment created by the official authorized bodies.

Child protection is all activities to guarantee and protect children and their rights so that they can live, grow, develop, and participate, optimally in accordance with human dignity and dignity, and get protection from violence and discrimination.

Child protection in Indonesia means protecting the potential of human resources and developing a complete Indonesian human being, towards a just and prosperous society, spiritual material based on Pancasila and the 1945 Law. Child protection efforts must begin as early as possible, so that one day can optimally participate for nation and state development.

Law Number 23 Year 2002 concerning Child Protection emphasizes that the responsibilities of parents, family, community, government and the state are a series of activities carried out continuously in order to protect children's rights. Efforts to protect children need to be carried out as early as possible, namely from the fetus in the womb to children aged 18 (eighteen) years. Law Number 23 Year 2002 concerning Child Protection lays the obligation to provide protection to children based on the principles, namely:

1) Non-Discrimination;

2) The best interests of the child;

3) The right to life, survival and development; and

4) Appreciation of children's opinions.

Child protection efforts need the role of the community, whether through child protection institutions, religious institutions, non-governmental organizations, social organizations, social organizations, mass media, or educational institutions. So, for the sake of complete human development and civilization, everyone is required to seek child protection in accordance with their abilities and abilities. Every child has the right to carry out their obligations to fight for their survival, selfdevelopment, and protection for themselves. 


\section{c. $\quad$ Rights and Obligations of Children}

Children's rights are part of human rights that must be guaranteed to be protected, and fulfilled by parents, families, communities, governments, and the State. Every child has the right to protection from physical and mental violence and discrimination as well as civil rights and freedoms. Based on Law Number 23 of 2002 concerning child protection, children's rights are regulated in Article 4 through Article 18. And in Article 19 the child obligations are regulated.

Children's rights in the criminal justice process are the result of interactions that are interrelated and influence with others. Mental, physical, social and economic aspects are factors that must be taken into account in the development of rights. To get justice requires a balance between rights and obligations.

Likewise, the implementation of rights and obligations for children who are victims of criminal offenses need to get legal assistance and protection in order to achieve the expected justice. But if it is necessary to underline is in terms of treating children must pay attention to conditions, physical and mental, social conditions and age where at each level of age children have different abilities. Legal certainty needs to be endeavored for the continuity of child protection activities and prevent the occurrence of abuses that bring negativity in the implementation of legal protection.

\subsection{Overview of Criminalization}

\section{a. Definition of Criminalization}

L.H.C. Hullsman once stated that the sentencing system (the sentencing system) is a statutory regulation relating to sanctions and punishment (the statutory rules relating to penal sanction and punishment). According to Barda Nawawi Arief, if the definition of punishment is broadly interpreted as a process of giving or imposing a criminal by a judge, then it can be said that the criminal system includes the entire statutory provisions governing how the criminal law is enforced or operationally concretely so that a person is sanctioned (the law criminal).

This means that all statutory regulations regarding Substantive Criminal Law, Formal Criminal Law and Criminal Procedure Law be a unified criminal system. Barda Nawawi Arief departs from the above understanding stating that if the statutory rules are limited to substantive criminal law contained in the Criminal Code, it can be said that the entire provisions in the Criminal Code, both in the form of general rules and specific rules regarding the formulation of acts criminal, is essentially a unity of the criminal system.

All statutory rules in the substantive criminal law sector consist of general rules and special rules. General rules are contained in the Criminal Code (Book I), and special rules are contained in Criminal Code Books II and Book III, as well as in Special Laws outside the Criminal Code. These special rules generally contain the formulation of certain criminal acts, but they can also contain special rules that deviate from general rules.

\section{b. $\quad$ Model of Criminal Against Children}

The Model of Criminal Against Children Can be put forward regarding the judicial model in enforcing criminal law against children. Gordon Bazomore in his writings "Three Paradigms of Juvenile Justice" introduces three features or models of juvenile justice, namely: (a) The model of training individual actors (individual treatment models); (b) A retributive model (retributive model); and the Restorative Model

As for the description of the model of punishment for the child can be seen from the description below:

1) Individual Coaching Model

Children have the right to be fostered so that they can carry out their obligations as good citizens so that as early as possible can prevent children from committing further crimes. One of the best coaching 
comes from the family, but sometimes there are social coaching interventions in the family which often shows the attitude that to resolve deviations committed by children is resolved by deliberation, persuasion or expulsion of children as perpetrators of crime.

In the fostering model of individual perpetrators and retributive models are based on therapeutic medical methods, look for reasons for children to commit crimes and consider children as disorders or victims that require therapeutic services to overcome them. The weaknesses of this model are no guarantee of stigmatization or labeling, paternalism, weak legal guarantees and have not been able to formally direct the need for effective sanctions against child offenders. And the decisions in this model are ambivalent and disobedient, tend to hide the intention of punishment in the name of public safety, so that in this case the interests of children become neglected.

\section{2) Restorative Justice}

The restorative justice model in handling child cases can be a reference and consideration by the judge. Because in principle restorative justice recognizes 3 (three) stakeholders in determining the settlement of a child case, namely: (1) the victim; (2) perpetrators; (3) community. However, the spirit of restorative justice is not seen in Law Number 4 of 2004 concerning Judicial Power, and Law Number 3 of 1997 concerning Juvenile Court. The judge did not explicitly give his authority to decide the settlement of the case of children with a system of handling restorative justice.

The authority of the juvenile trial in this law only regulates the examination and resolution of juvenile delinquents, that is, children who commit criminal acts or who commit acts which are declared prohibited for children, and do not yet reflect restorative justice in favor of children and pay full attention to the interests of children.

Paying attention to the characteristics and characteristics of a restorative juvenile justice model that does not only have a single dimension and control of the perpetrators (such as a model of individual and retributive development of the perpetrators) but has a plural dimension of the perpetrators, victims and the community, no punitive does not leave a stigma, does not alienate the offender's child with the family and the peer group, is quite promising and needs to be considered in the handling of children in conflict with Indonesian law in the future.

The restorative justice model has not been fully used as a reference by judges in handling child cases because of 3 (three) factors, namely:

a) The legal instruments underlying the juvenile justice system have not yet adopted this approach in its entirety.

b) The interpretation and construction of judges is built based on the legal positivism approach.

c) Judges who try child cases do not take sides with the victims and do not have an understanding of children's rights.

In the restorative justice model, a crime is considered a violation of the state, which focuses on guilt, blame and the past regarding whether or not an act was committed.

\section{3) Restorative Model}

In the restorative model, crime is defined as a form of violation of someone by another person. The solution of the problem is focused on the responsibilities and obligations and the future of the offender.

Settlement of cases with the restorative justice model prioritizes normal dialogue and negotiations between the perpetrators, victims and families as well as community participation. In addition, in the 
settlement there are efforts to provide restitution (replacement) as a way to provide recovery to the two parties through reconciliation / restoration which is the main objective of the restorative settlement.

\section{Application of the Best Interest Principle for Children in Law Number 11 of 2012 concerning the Juvenile Justice System in Cases of Sexual Abuse at the Central Lombok Police Station}

\subsection{Overview of Sexual Abuse}

a. Definition of Sexual Abuse

According to Arif Gosita, rape can be formulated from several forms of behavior which include the following:

"The victim of molestation must be a woman, without age limit (object). Whereas there is also a man who was raped by a woman. Victims must experience violence or threat of violence. This means there is no agreement from the victim regarding the intentions and actions of the perpetrators."

Intercourse outside of marriage is the goal to be achieved by committing violence or threat of violence against certain women. In reality there is also intercourse in marriages that are forced by violence, which cause mental and physical suffering. Although these actions cause victims suffering, they cannot be classified as a crime because they were not formulated in advance by the legislators as a crime.

From the formulation above shows that the position of women is placed as an object of sexual violence (sexual abuse) because women are identical to the weak, and men as the perpetrators are known to have very strong power that can force coercion in whatever way they want even though by means of violence or threat of violence. The function of the violence in relation to criminal offenses is as follows:

1) Violence in the form of a way to do an action. Violence here requires conditions due to the helplessness of the victim. There is a causal verb and between violence and the helplessness of victims. For example, violence in sexual abuse, which is used as a way of forcing intercourse. Also, on extortion (Article 368), which results in the victim being helpless, with the helplessness that causes the victim to be forced to hand over objects, make debt or write off receivables.

2) Violence in the form of an act that is prohibited in a criminal offense is not a way to commit an act. For example, violence in Article 211 or Article 212.

Threats of violence have important aspects in molestation which include the following: Objective aspects, are (a) tangible manifestations of the threat of violence in the form of acts of preparation and may have been the beginning of an act of carrying out a larger act of violence which is perfect; and (b) causes people to accept violence to become psychologically helpless, in the form of fear, anxiety (subjective aspects that are objectified).

The subjective aspect is the emergence of a belief for the recipient of violence (victims) that if the will of the perpetrators they ask is not fulfilled which in case has intercourse with him, then the violence will actually be realized. This aspect of trust is very important in the threat of violence because if this trust does not arise in the victim, it is unlikely that the victim will allow an act to be done against him.

The perpetrators of molestation of children who can also be called chid molesters, can be classified into five categories, namely:

1) Immature: perpetrators of sexual abuse are caused by the inability to identify themselves with sexual roles as adults.

2) Frustrated: the perpetrators commit crimes (molestation) as a reaction against sexual frustration that is emotional to adults. It often happens they turn to their own children (incest) when they feel out of balance with his wife. 
3) Sociopathic: the perpetrators of molestation who do things with people who are completely unfamiliar to him, an action that comes out of aggressive tendencies that sometimes arise.

4) Pathological: perpetrators of molestation who are unable to control sexual urges as a result of psychosis, mental weakness, organ weakness or premature senile deterioration.

5) Miscellaneous: which does not include all the categories above.

b. $\quad$ Elements of obscenity

Obscenity is a crime that is generally regulated in Article 285 of the Criminal Code, which reads as follows:

"Anyone with violence or threat of violence forces a woman who is not his wife to have intercourse with him, threatened with rape with a maximum prison sentence of twelve years."

Sexual abuse and threats of violence to have sex with minors are also regulated in Law No. 23 of 2002 jo. Law Number 35 Year 2014 No. Government Regulation in Lieu of Law (Perppu) Number 1 Year 2016 concerning Child Protection in Article 81 paragraph (1) and (2) which states:

1) Every person intentionally commits violence or threat of violence forcing a child to have intercourse with him or with another person, sentenced to a maximum imprisonment of 15 (fifteen) years and a minimum of 3 (three) years and a maximum fine of Rp. 300,000,000.00 ( three hundred million rupiah) and at least Rp 60,000,000.00 (sixty million rupiah).

2) Criminal provisions referred to in paragraph (1) shall also apply to anyone who intentionally commits deception, a series of lies, or entices the child to have intercourse with him or with another person.

\subsection{Police Force In Law Number 2 of 2002 concerning Police}

\section{a. $\quad$ Police Understanding}

Understanding Police in the history of the meaning of the police have different interpretations, the current police with the initial found very different terms. First discovered with the Greek word Politca, meaning the entire city government.

In the Netherlands the term police was known through the concept of Chess Praja and Van Vollen Honen which divided the government into 4 (four) parts, namely:

1) Bestur

2) Politic

3) Rechtspraak

4) Regeling

Thus, the police are given understanding and public order as well as the protection of people and their objects from unlawful acts. Law Number 2 of 2002 concerning the Indonesian National Police in Article 1 paragraph (1) explains that the Police are all matters relating to the functions and institutions of the police in accordance with statutory regulations.

The term police in this Law contains two meanings, namely the function of the police and the police agency. In Article 2 of Law Number 2 of 2002 concerning the Indonesian National Police, the 
function of the police as one of the functions of the government in the field of maintaining security and public order, law enforcement, protectors, protectors, and servants to the public.

There are various terms that are known in the efforts of the police to deal with criminal acts, including criminal policy, criminal policy, or police strategy is an attempt to tackle crime through the enforcement of criminal law, which is rational, namely fulfilling a sense of justice and usability.

In the context of overcoming criminal acts against various means as a reaction that can be given to perpetrators of crime, in the form of criminal and non-criminal means, which can be integrated with one another. Laws are formed based on the desires and awareness of everyone in the community, with the intention that the law can run as aspired by the community itself, which requires harmony and peace in the association of living together.

People who commit a crime will be responsible for the act with a criminal if they have a mistake, someone has a mistake when doing an act viewed in terms of the community shows a normative view of the wrongdoing. In the Big Indonesian Dictionary W.J.S. Poerwodarmita stated that the term police mean:

1) Government agencies (a group of civil servants) tasked with maintaining security and public order.

2) Public servants in charge of maintaining security and public order.

\section{b. $\quad$ Police Authority}

Police authority Law Number 13 of 1961 concerning the basic provisions of the state police, as well as Law Number 8 of 1981 concerning the Criminal Procedure Act, there is the authority of the state police in investigating a Criminal case.

1) The Dutch General Authority regarding police authority was firmly stated by the supreme court of Hooge Raad on March 19, 1917 that police actions could be considered rechmatig even without "special wettelijk machtingin" or the granting of special powers by the Law. Indonesia has not been explicitly stated in Law No. 13 of 1961, where police actions are always considered legitimate if their actions do not exceed their limits and authority and do not violate human rights and measures in the public interest.

2) Special Authority

As stated in the previous section, this special authority is the authority granted by the National Police in the framework of performing its function as a state instrument. Specifically as an investigation as in Article 13 of Law Number 13 of 1961 which contains that: for the purposes of investigation, the State Police has the authority:

a) Receiving Complaints

b) Checking identification

c) Take a fingerprint and photograph someone

d) Catch people

e) Body search

f) Hold people temporarily

g) Calling people to be heard and examined

h) Bring in experts

i) Search the yard, house, warehouse, land, sea and air transportation

j) Taking items to be used as evidence

k) Take other actions. 
Everything described above is the authority of the police investigator based on the Criminal Procedure Code and regarding Law No. 8/1981 regarding KUHAP is the same as the authority in Law No. 13/1961.

According to Barda Nawawi Arief, the implementation of the politics of criminal law must go through several policy stages as follows:

1) Formulation Stage The formulation stage is the stage of criminal law enforcement in abstract by the law-making body. In this stage, the legislators conduct activities to choose values that are in accordance with the present and future circumstances and situations, then formulate them in the form of criminal legislation to achieve the results of the legislation that are best in the sense of meeting the requirements of justice and usability. This stage is called the legislative policy stage.

2) Application Stage The application stage is the stage of criminal law enforcement by law enforcement officials from the police to the court. In this stage, law enforcement officers have the duty to enforce and implement criminal laws that have been made by lawmakers. In carrying out this task, law enforcement officials must hold fast to the values of justice and the effectiveness of this stage can be called the judicial stage.

3) Execution Phase That is the stage of law enforcement (implementation) concretely by the criminal implementation apparatuses. In this stage the criminal implementing apparatus has the duty to enforce the criminal legislation that has been made by the legislators through the application of the criminal law that has been determined in the court's ruling.

The stages in the three stages of criminal law enforcement above are a process of law enforcement that is complementary and interconnected with one another. In carrying out the process of law enforcement must be upheld by the values of justice to achieve a goal for the continuity and order of the law.

In carrying out law enforcement, law enforcement officials must be guided by the criminal law regulations as the legal basis. The stages in the three stages of criminal law enforcement above are a process of law enforcement that is complementary and interconnected with one another.

In carrying out the process of law enforcement must be upheld by the values of justice to achieve a goal for the continuity and order of the law. In carrying out law enforcement, law enforcement officials must be guided by the criminal law regulations as the legal basis.

Crime prevention policies with non-penal means include the use of social facilities to improve certain social conditions, but indirectly affect efforts to prevent crime. As explained above, the penal policy is a repressive policy after a crime has occurred by determining two central problems namely what should be a criminal offense and what sanctions should be used or imposed on the offender.

The path of penal policy that is by implementing part of social policy is essentially also an integral part of efforts to protect society (social defense) by applying criminal law (criminal law application). Whereas the non-penal policy is a policy more towards the nature of preventing criminal acts or prior to the occurrence of criminal acts by overcoming these crime factors. Tackling criminal acts, not only is a policy required for law enforcement, but there must also be value in it. Like facing the crime of sexual abuse, is an act that is inappropriate / despicable in the community and violates religious values. At first the act was not blameworthy, but then with the development of culture, values, and norms, it was considered despicable, so a policy was made with penal sanctions in it. But not all deeds were deemed inappropriate.

In determining a criminal threat to a criminal offense, the criteria should also be considered, namely, the actual purpose of criminal law, the determination of an act is a criminal offense, a comparison between the means and the results, and the ability of law enforcement agencies to enforce the law in the community. 
Considering that efforts to tackle crime through non-criminal channels are more preventive in nature, the main objective is to deal with conducive factors, among others, to focus on problems or conditions which can directly or indirectly lead to criminal acts. Thus, non-penal if viewed from the perspective of criminal politics at a macro and global level, non-penal efforts occupy the key and strategic positions of the overall criminal political effort. The non-penal route is by:

1) Prevention without crime (prevention without punishment), including the application of administrative sanctions and civil sanctions.

2) Influencing community views on crime and coaching through mass media (influencing views of society on crime and punishment).

\subsubsection{Application of the Principle of Best Interest for Children in Cases of Sexual Abuse in the Central Lombok Police Station}

Children who are dealing with the law need special protection as regulated in the Child Protection Act and the Human Rights Act. In the provisions of Article 16 paragraph (3) of Law Number 23 of 2002 concerning Child Protection as amended to Law Number 35 of 2014 and Article 66 paragraph (4) of Law Number 39 of 1999 concerning Human Rights expressly states that :

"Arrest, detention, or imprisonment of a child is only carried out if in accordance with applicable law and can only be done as a last resort. Law enforcement efforts in criminal proceedings carried out by the police, prosecutors and judges, in substance have already contained criminal sentences and sentences ".

The formal justice process that starts from the act of arrest, detention, and then ends in imposing sanctions on imprisonment against children can have bad implications on the child's future, so the law mandates that the formal justice process against children be a last resort (ultimum remedium) when other efforts are not it works.

In reality, the case of a child crime in the Central Lombok Police jurisdiction is not a criminal offense, but the figure is quite high, but it is still classified as a criminal offense that deserves attention. The crime of children who entered the Women's and Children's Services Unit (PPA) of the Central Lombok Police Station from 2017-2019 experienced changes. During 2017 until 2018 there was an increase, from 3 cases to 4 cases of child crime. One of the cases currently being handled by the Central Lombok Police Station is a case relating to molestation of children with ID Number: Sp.Sidik/607/X/2018/Reskrim, 12 October 2018.

Based on the results of the examination of the molestation case with Number: Sp. proven to violate Article 82 Paragraph 1 of the Law of the Republic of Indonesia Number 17 of 2016 concerning the Second Amendment to the Shrimp of the Republic of Indonesia Number 23 of 2002 concerning child protection.

Based on the results of interviews with Imran as the investigator of Central Lombok Polres PPA Unit and a juridical analysis conducted on the suspect, that Central Lombok Polres PPA Unit Investigators conducted an analysis of the case, as follows: Fornication of Children "as referred to in Article 82 Paragraph (1) and Law of the Republic of Indonesia Number 17 Year 2016 concerning Second Amendment to Law Number 23 of 2002 concerning Child Protection carried out by a suspect on behalf of Putra Jayadi and has been proven to meet the elements Article 82 Paragraph (1) Law of the Republic of Indonesia Number 17 Year 2016 concerning Second Amendment to Law No. 23 of 2002 concerning Child Protection.

In order to provide maximum legal protection for child suspects, the efforts made by the Central Lombok Police Station are to deploy members to conduct investigations in accordance with their duties and authorities as stipulated in the existing laws and regulations. 
The legal actions carried out by the Central Lombok Police PPA unit in the abusive crime against children mentioned above, including:

a. Receive reports or complaints from someone about a crime (Police Report Number: LP/389/VIII/2018/NTB/Res.Loteng, 31 August 2018);

b. Call verbally on witnesses who have been present and make Minutes of Investigation;

c. Checking the identity of the suspect (Examination of the Identity of Putra Jayadi);

d. Not arresting and detaining a suspect.

e. Conduct examination and seizure of Evidence from Suspects and Witnesses (Making an Application for Approve of Search and Confiscation, Confiscation Order Number: Based on the seizure warrant number: Sp Sita/96/X/2018/Reskrim, dated October 12, 2018, confiscation has been carried out on evidence: from the victim's hand on Thursday 19 July 2018 at the Central Lombok Police Station, in the form of: 1 (one) pink shirt and 1 (one) black and white checkered shorts.

f. Legal action in the form of seizure has been requested for seizure approval from the Chairman of the Praya District Court by letter number: B/96.b/X/2018/Reskrim, October 15, 2018.

g. Take fingerprints and photograph suspects;

h. Calling people to be heard and examined as suspects or witnesses (Summons and examinations of witnesses namely Rumisah, Najwa Khaira Wilda, Sahrudin and Putra Jayadi suspects, subsequently prepared Minutes of Examination of each);

i. Bring in experts who are needed in the relationship in the examination of the case; in this case the psychologist, Pujiarohman.

j. Carry out other actions according to responsible law;

As described above, the Central Lombok District Police investigator in handling cases involving children as perpetrators and victims, pays close attention to the principle of the best interests of children as mandated by the juvenile justice system, implementation of the best interests of children by the Unit Investigator PAA in Central Lombok Police Station, we can see in the provisions of the Articles below:

The provisions of Article 3 reads:

Every child in the criminal justice process has the right:

a. Treated humanely with due regard to needs according to age;

b. Separated from adults;

c. Obtains legal assistance and other assistance effectively;

d. Carries out recreational activities;

e. Freedom from torture, punishment or other cruel, inhuman or degrading treatment and dignity;

f. Not sentenced to death sentence or life imprisonment;

g. Is not arrested, detained or imprisoned, except as a last resort and in the shortest amount of time;

h. Obtain justice before the Juvenile court that is objective, impartial, and in a hearing that is closed to the public;

i. The identity is not published;

j. Gets the assistance of parents / guardians and people trusted by the child;

k. Gets social advocacy;

1. Obtains a private life;

m. Gain accessibility, especially for children with disabilities;

n. Gets an education;

o. Obtains health services; and

p. Obtains other rights in accordance with statutory provisions. 
Article 18 of Law Number 11 of 2012 concerning the Criminal Justice System for Children:

"In handling cases of Children, Victim Children and / or Witness Children, Community Guidance, Professional Social Workers and Social Welfare Workers, Investigators, Public Prosecutors, Judges, and Advocates or other legal aid providers must pay attention to the best interests of the Child and cultivate a family atmosphere. still maintained. "“

\section{Article 22}

'Investigators, Public Prosecutors, Judges, Community Guides, Advocates or other legal aid providers, and other officers in examining the cases of Children, Victim Children, and / or Witness Children do not use official gowns or attributes.

\section{Article 23 Paragraph (1)}

At each level of examination, children must be given legal assistance and be accompanied by a Community Guidance or other companions in accordance with the provisions of the legislation. (2) At each level of examination, the Victim Child or Witness Child must be accompanied by a parent and / or person trusted by the Victim Child and / or Witness Child, or Social Worker. (3) In the case of parents as suspects or defendants in the case being examined, the provisions referred to in paragraph (2) do not apply to parents.

Article 27 Paragraph (1) and Paragraph (2)

(1) In investigating the case of the Child, the Investigator is obliged to ask for consideration or advice from the Community Guidance after the crime has been reported or complained.

(2) If deemed necessary, the Investigator may seek consideration or advice from education experts, psychologists, psychiatrists, religious leaders, Professional Social Workers or Social Welfare Workers, and other experts.

In the case of a child who conflicts with the law, we must also pay attention to the concept of the best interest of the child. The principle of the best interest of the child, provides space for the state and society to intervene, and provides space for children to participate.

The Convention on the Rights of the Child as an instrument of children's rights also considers the reduction of the rights of parents and families to accommodate the process of evolving capacities of the child. Therefore, the best interests of the child become the main consideration. A child who conflicts with the law must have a different way of handling cases, the trial process and the application of sanctions must also be distinguished from adults.

Ordinary children's mischief is also called Junevile Delinquency as in the opinion of some experts about Junevile Deliquency. According to Kartini Kartono, what is meant by Junquile Deliquency is:

"Evil/evil behavior, or crime/delinquency of young children, is a symptom of illness (pathology) socially in children and adolescents caused by a form of social neglect so that they develop a form of neglect of deviant behavior".

Paul Moedikno states that the junctions of delinquency are as follows:

a) All acts of adults are a crime, for children is delinquency. So, all actions that are prohibited by criminal law, such as stealing, torturing, killing, and so on.

b) All deviations from the norms of certain groups that cause unrest in society, for example wearing rude trousers, and so on.

c) All actions that show the need for social protection, including homeless, beggars and others. 
Criminal imprisonment of children through the juvenile justice system as an ultimum remedium or the last resort principle is one form of protection against children. This is seen in the Convention of the Right of the Child which has been ratified by the Government of Indonesia with Presidential Decree Number 36 of 1990 in Article 37 letter (b) which states that: "States parties must guarantee that no child can be deprived of his freedom unlawfully or arbitrarily."

The arrest, detention, or imprisonment of a child must be in accordance with the law, and must be used only as a last resort and for the shortest period of time. This is confirmed again in Article 66 paragraph (4) which states as follows:

"The arrest, detention, or crime of a child may only be carried out in accordance with applicable law and can only be carried out as a last resort."

Article 37 letter (b) of Presidential Decree Number 36 of 1990 in conjunction with Article 66 Paragraph (4) above clearly shows the function of criminal law as ultimum remedium in resolving child cases. Protection and guidance for children who are in conflict with the law must also pay attention to the principle of parens patriae.

The Parens Patriae Principle which means that the authorities must act if children need help, while children who commit crimes are not convicted but must be protected and given assistance.

Absolute theory (retributive theory), views that punishment is a retaliation for mistakes that have been made, so it is oriented to the action and lies in the crime itself. Criminalization is given because the perpetrator must accept the sanction for the sake of his mistakes. According to this theory, the basis of punishment must be sought from the crime itself, because the crime has caused suffering for others, in return (vergelding) the perpetrator must be given suffering.

Relative theory (deterrence), this theory views punishment not as retaliation for the wrongdoing of the perpetrator, but as a means of achieving beneficial goals to protect society towards prosperity. From this theory emerged the aim of punishment as a means of prevention, namely general prevention aimed at society. Based on this theory, the sentence imposed to carry out the purpose or purpose of the sentence, namely, to improve public dissatisfaction as a result of the crime. The purpose of punishment must be viewed as an ideal, apart from that, the purpose of punishment is to prevention crime.

The combined theory (integrative) bases the criminal on the principle of retaliation and the principle of orderly defense of the public order, in other words the two reasons become the basis of criminal conviction. Basically, the combined theory is a combination of absolute theory and relative theory. Combined the two theories teach that sentencing is to maintain the rule of law in society and improve the person of the criminal.

Based on the description above, the application of the best interests principle for children as perpetrators of sexual abuse in the Central Lombok Police Station is in accordance with the provisions of the child protection law and the law on the piana justice system, where children as suspects are not treated the same as adults, and the suspect is given an obligation to report 2 times a week on Monday and Thursday. In addition to this, one form of application of the principle of best interests for children carried out in the Central Lombok Police Station is to provide opportunities for schooling to suspects because the suspects are still in the learning process. The suspect was examined in a special room in the room of the PPA unit and the investigation was specifically for the PPA and did not use official clothing. Whereas the investigation process is the same as the adult investigation process, but the treatment is different. Because after all children are the next generation that must be protected. 


\section{Conclusion}

Based on the description above, the following conclusions can be drawn:

1. The regulation of the best interests principle for children in Law Number 11 Year 2012 concerning the Juvenile Justice System is contained in the provisions of Article 2 letter d, Article 3, Article 18, Article 22, Article 27 namely the regulation of children's rights in the criminal justice system children carried out based on the principle of the best interests of children.

2. The application of the principle of best interest for children in Law Number 11 of 2012 concerning the Juvenile Justice System in the case of sexual abuse in the Central Lombok Police Station, among others, is carried out in the form of a suspect not treated the same as an adult (Article 3 letter b), accompanied by The suspect psychologist is given the opportunity to go to school (Article 3 letter $n$ ), the suspect is examined in a special room that is the room of the PPA unit and the investigator is also specifically the PPA investigator and dressed in non-official service (Article 22), as mandated by the law.

\section{Recommendation}

Based on this description, the following recommendations can be recommended:

1. The government should clarify the regulation of the principles of the best interests of the child in the juvenile justice system law so as not to cause multiple interpretations in the enforcement of criminal law especially in child crime.

2. Law enforcement officials should understand and apply the principles or principles of the best interests of children in order to protect children's rights as mandated by the law.

\section{References}

Books

Arifin, 2007, Pendidikan Anak Berkonflik Hukum Model Konvergensi Antara Fungsionalis dan Religious, Alfabeta, Bandung.

Burhan Ashofa, 2001. Metode Penelitian Hukum, Jakarta: Rineka Cipta.

Hadi Supeno, 2010. Kriminalisasi Anak Tawaran Gagasan Radikal Peradilan Anak Tanpa Pemidanaan, PT Gramedia, Jakarta.

Iman Soepomo, 2010. Hukum Perburuhan Bidang Kesehatan Kerja (Perlindungan Buruh), Pradnya Paramita, Jakarta.

F.A.M. Stroink dan J.G. Steenbeek, 1998, Inleiding in Het Staats-en Administratiefrech, Sam-som H.D. Tjeenk Willink, Alphen aan den Rijn, Nederland.

JJH. Bruggink, 1999. Refleksi Tentang Hukum, Citra Aditya Bakti, Bandung.

Marlina, 2009. Peradilan Pidana Anak di Indonesia Pengembangan Konsep Diversi dan Restorative Justice, PT Refika Aditama,Bandung. 
Maidin Gultom, 2014, Perlindungan Hukum Terhadap Anak, PT. Refika Aditama, Bandung.

Mochtar Kusuma Atmaja, 2016. Fungsi dan perkembangan Hukum Dalam Pembangunan Nasional, Cetakan I, Bina Cipta, Bandung.

Paul Scolten dalam Arif Sidarta, 1996. Refleksi Tentang Hukum, Cet ke2, PT. Citra Aditya Bakti, Bandung.

P. Scolten dalam Chainur Arrasjid, 2010, Dasar-Dasar Ilmu Hukum, Cet-3, Sinar Grafika, Jakarta.

Philipus M. Hadjon, 2002. Perlindungan Hukum Bagi Rakyat di Indonesia, Cetakan I, Bina Ilmu, Surabaya.

Ridwan HR, 2002, Hukum Adsministrasi Negara, UII Press, Yogyakarta.

Soehino, 2008, Ilmu Negara, Cet. VIII, Liberty, Yogyakarta.

Sjachran Basah, 2008. Perlindungan Hukum Atas Sikap Tindak Administratif Negara, Cetakan I, Alumni, Bandung.

Sudikno Mertokusumo, 1993. Bab-bab Tentang Penemuan Hukum, Citra Aditya Bakti, Yogyakarta.

Soerjono Soekanto dan Sri Mamudji, 2004. Penelitian Hukum Normatif Suatu Tinjauan Singkat, Jakarta : PT.Raja Grafindo Persada.

R. Subekti,dkk, 2005, Kamus Hukum, Pradnya Paramitha.

Sudarsono, 2012, Kamus Hukum, Rineka Cipta, Jakarta.

Regulations

Indonesia, the 1945 Constitution of the Republic of Indonesia

Indonesia, Law No. 8 of 1981 concerning the Criminal Procedure Code.

Indonesia, Law Number 02 of 2002 concerning the Indonesian National Police.

Indonesia, Law Number 23 of 2002 concerning Child Protection

Indonesia, Law Number 11 of 2012 concerning the Criminal Justice System for Children.

\section{Copyrights}

Copyright for this article is retained by the author(s), with first publication rights granted to the journal. This is an open-access article distributed under the terms and conditions of the Creative Commons Attribution license (http://creativecommons.org/licenses/by/4.0/). 